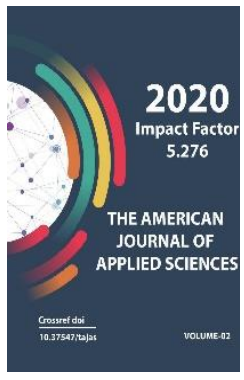

Copyright: Original content from this work may be used under the terms of the creative commons attributes 4.0 licence.

\section{Physico-Mechanical Properties Of Irrigated Meadow Soils Of The Bukhara Region (On The Example Of The Zhandar District)}

\author{
Nazarova S.M. \\ Lecturers Of Bukhara State University, Uzbekistan \\ Zaripov G.T. \\ Lecturers Of Bukhara State University, Uzbekistan \\ Mamurova M.O. \\ Lecturers Of Bukhara State University, Uzbekistan
}

\title{
ABSTRACT
}

The article provides data on the physical and mechanical properties of irrigated meadow soils in the Zhandar region. Depending on the mechanical composition, the degree of salinity and cultivation, it varies within a wide range of physical and mechanical properties, there are certain differences caused by their genesis and regional characteristics.

\section{KEYWORDS}

Land resources, agriculture, soil fertility, efficiency, mechanical composition, hardness, density, specific gravity, soil porosity, humus, solid residue, nitrogen, phosphorus, potassium

\section{INTRODUCTION}

A number of scientific studies are being carried out in the Republic aimed at further developing agriculture, preserving, reproducing, increasing soil fertility, efficiently using land resources, optimizing the ecological state, assessing the water-physical, technological, agrochemical properties and the reclamation state of soils. In this plan, special attention is paid to the development of agrotechnical, agrophysical measures, taking into account soil and climatic conditions, the widespread use of scientific and practical achievements in 
improving, restoring and increasing soil fertility. "Population growth over the next 35 years will require an increase in food production of about 60\%." Development of scientifically based measures aimed at increasing soil fertility. Improving the efficiency of irrigated lands, protecting the soil cover from degradation processes and preventing them is one of the urgent tasks.

\section{Materials and Methods}

This study was carried out in accordance with the priority direction of the development of science and technology in the republic. Irrigated soils, which are widespread in the Zhandar region, differ in their properties and characteristics not only in soil zones, but also in soil and climatic conditions. On the problem of studying soil fertility, its management and other properties, large-scale scientific research has been carried out both abroad and in our republic.

Irrigated soils of the Bukhara oasis not only differ in the properties of the steppe zone, they differ in climatic districts.

The morphogenetic structure, geographical distribution, reclamation state, agrophysical and agrochemical properties of the soils of the Bukhara oasis and other regions have been studied by many scientists, such as

K.Gafurov, S.A.Abdullaev [3.1982; p.130], U. Tozhiev [9.2004; p.158-159], X.T.Artikova [1.2005; p.28, 2.2019; p.62], M.A. Mazirov, S.V. Makarychev [6.2018; p.605], R. Kurvantaev [4. 2000; p.40, 5.2019; p.91-95], Nazarova S.M. [7.2016; p.60-66, 8.2018; p.187-190], Sharipov.O.B., Gafurorova L.A. [10.2018; p.7679], Hakimova N., Kurvantaev R. [11. 2020; p.6871] and others. However, scientific research on the study of the modern meliorative state, physical and mechanical properties of irrigated meadow soils in the Zhandar region has not been carried out sufficiently.

The aim of the research is to develop recommendations for the correct organization of soil cultivation by determining the physical and mechanical properties and assessing the reclamation state of irrigated meadow soils common in the Zhandar region.

The studies were carried out in soil-field and analytical-laboratory conditions. The reliability of the data obtained was carried out using the Microsoft Excel program on the basis of the "Field experiment methodology" by B.A. Dospekhova.

\section{RESEARCH RESULTS AND DISCUSSIONS}

The irrigated meadow soils of the Zhandar District are heavy and medium loamy in terms of the content of water-soluble salts, not saline (dense residue $0.150-0.375 \%$ ), in some places (mainly chlorine) slightly saline (0.014-0.031\%).

In the studied soils, the humus content in the arable and subsoil layers is $0.94-0.63 \%$. At the same time, in the lower layers, no sharp differences are observed in the humus content, and along the sections, the humus content is $0.41-0.30 \%$.

The influence of the age of irrigation on the content of nutrient reserves (nitrogen, phosphorus and potassium) is clearly seen. In the irrigated meadow soils of the Zhandar region, nitrogen is 1.9-3.2 $\mathrm{t} / \mathrm{ha}$, phosphorus is $6.5-14.5 \mathrm{t} / \mathrm{ha}$, potassium is $51.4-106.5 \mathrm{t} / \mathrm{ha}$.

Physicomechanical properties of irrigated soils in the Zhandar region, it is noted that the soils are distinguished by their mechanical composition by their originality in administrative and geomorphological regions formed on alluvial deposits of the lower part of the river. Zarafshan. Basically, the mechanical 
composition consists of the following particles: coarse sand (1-0.25mm), medium sand (0.25$0.1 \mathrm{~mm})$, and fine sand $(0.1-0.05 \mathrm{~mm})$. The mechanical composition of the soils of the Zhandar District is composed of sandy, sandy loam, light, medium, heavy loams.

The specific gravity is a stable unit; it depends on the chemical, mineralogical composition and on the supply of humus to the soil. In irrigated meadow soils in the lower reaches of the Zerafshan in the region, the specific weight is $2.58-2.66 \mathrm{~g} / \mathrm{cm} 3$.

Bulk mass is a variable and different unit, depending on the various processes occurring in the soil.

In the upper arable layer from the soil, the bulk density varies between 1.27-1.63 g / cm3, depending on the humus content, texture, salinity and other properties. Among the upper layers, the highest density $(1.53-1.63 \mathrm{~g} / \mathrm{cm} 3)$ is observed in the soils of the Zhandar region.

Side panels of old-irrigated meadow soils, as a result of numerous visits of heavy equipment and non-observance of the irrigation regime, the optimal bulk density increases. It was determined that under the conditions of irrigated meadow soils, their density increases with weighting of the mechanical composition (Table 1).

In irrigated soils, the movement of water, the content of soluble salts, the retention of moisture, and the provision of air to the root system are directly related to the porosity of the soil. In the studied meadow soils, the total porosity, depending on the duration of irrigation, varies over the genetic layers of the profile (42-51\%) within wide limits.

\section{Table 1}

\begin{tabular}{|c|c|c|c|c|c|c|}
\hline Cutting depth, cm & $0-35$ & $35-50$ & $50-75$ & $75-105$ & $105-132$ & $132-180$ \\
\hline Specific weight, g / cm3 & 2,58 & 2,67 & 2,64 & 2,60 & 2,66 & 2,66 \\
\hline Bulk weight, g/cm3 & 1,34 & 1,49 & 1,53 & 1,52 & 1,53 & 1,48 \\
\hline Total porosity,\% & 48 & 44 & 43 & 42 & 42 & 45 \\
\hline
\end{tabular}

Soil hardness is a technological indicator of a property, it is of particular importance in fertility and soil. The hardness of the genetic soil layers in the Zhandar region, depending on the mechanical composition, layer moisture and density, varies from 5.1 to $16.7 \mathrm{~kg} / \mathrm{cm} 2$, high hardness values are confirmed by the data obtained for the subsoil layers (Table 2).

The resisting density for the development of plant roots in deep layers is determined by the penetrometer device, the results obtained show in the Zhandar region along the vertical horizons is $72.5-350 \mathrm{kPa}$. The greatest 
resistance is observed in the layer $105-132 \mathrm{~cm}$

(350 kPa).

Table 2

\section{Indicators of hardness of meadow soils of the Zhandar region}

\begin{tabular}{|c|c|c|c|}
\hline Horizon depth, cm & Hardness, $\mathrm{kg} / \mathrm{cm}^{2}$ & Vertical depth, & Hardness \\
& & $\mathrm{cm}$ & \\
\hline $0-35$ & 7,8 & 10 & 72,5 \\
\hline $35-50$ & 16,7 & 20 & 155 \\
\hline $50-75$ & 6,1 & 30 & 232 \\
\hline $75-105$ & 5,8 & 40 & 237 \\
\hline $105-132$ & 5,1 & 50 & 350 \\
\hline $132-180$ & 5,7 & 60 & 300 \\
\hline & & 70 & 250 \\
\hline
\end{tabular}

The soils widespread in various farms resists the development of the root system to varying degrees, especially there is a high resistance for plant roots of common soils in the Istiklal massif.

The content of agronomic valuable macroaggregates in the arable layer of old-irrigated medium loamy meadow soils in the Zhandar region in the Istiklal massif is $52-73 \%$.

\section{CONCLUSION}

1. Distributed in the lower part of the Bukhara oasis of soils, peculiar basic morphological features were formed in the process of prolonged irrigation. Soils of geomorphological regions are characterized by their peculiarity in the mechanical composition of soils and consist of sandy loam, light-, medium-, heavy-loamy varieties, mainly consist of the following fractions: coarse, medium fine sand

2. The specific gravity in the genetic layers varies in the range of $2.56-2.67 \mathrm{~g} / \mathrm{cm} 3$. The soils on the genetic horizons have different bulk density 1.27-1.63 $\mathrm{g} / \mathrm{cm} 3$, the total porosity in the upper layer is satisfactory 
(47-51\%), in the lower layers there is an unsatisfactory condition (38-42\%).

3. For genetic horizons, depending on the density and texture, the value of hardness varies from 5.1 to $16.7 \mathrm{~kg} / \mathrm{cm} 2$, the support of the soil for the development of roots is 72.5-350 kPa.

\section{REFERENCES}

1. Artikova Kh.T. Soils of the Bukhara oasis and their change under the influence of irrigation. Abstract. Cand. diss. Tashkent. 2005.-28p.

2. Artikova X.T. Evolution, ecological state and soil fertility of the Bukhara oasis. Avoref. diss. Doctor of Science (DSC), Tashkent, 2019, $62 \mathrm{p}$.

3. Gafurov K., Abdullaev S. Characteristics of the soil cover of the irrigated zone of the Bukhara region. Tashkent: Publishing house "Fan", 1982.-130s.

4. Kurvantaev R. Optimization and regulation of the agrophysical state of irrigated soils in the desert zone of Uzbekistan. Author. doct. diss. Tashkent. 2000.-p.40.

5. Kurvantaev R., Nazarova S.M. Agrophysical characteristics of irrigated meadow soils of the Bukhara oasis. // Modern trends in scientific support of the agro-industrial complex: Collective monograph. [editorial board: L. I. Ilyin and others; otv for issue VV Ogorkov]. Ivanovo, 2019 .-- S. 91-95.

6. Nazarova Sevara Mustakimovna, Gulmurot Taxirovich Z. Granulometric composition irrigated soils of bukhara region. Journal of critical reviews. issn- 2394-5125 vol 7, issue $17,2020 /$

7. Nazarova S.M., Kungirov H.N., Kurvantaev R.K., Dadamukhamedova M.R. The main factors of soil formation and their evolution in the Zerafshan valley. // In the collection: Ecological state of the natural environment and scientific and practical aspects of modern reclamation technologies Collection of scientific papers. Ryazan, 2016.S. 60-66.

8. Nazarova SM, Kurvantaev R. Mechanical composition of irrigated soils of the Bukhara oasis. I Actual problems of modern science. Scientific journal No. 4 (101), 2018. P. 187-190.

9. Tozhiev U.T., Nafetdinov Sh.Sh. Systemic research of diagnostics, classification and structure of soil cover in the Republic of Uzbekistan. 2004.S.-153-159.

10. Hakimova N., Kurvantaev R. Evolution of raflux soils of the midrange of the vallewy Zerafshan / ANNALI D / LTALIA Scientific Journal of Italy, VOL. 2. 2020 (4). Pp. 68-71.

11. Atoeva M.F., Safarova R.S. Pedagogical integration as a means of forming professionally important qualities among students of a medical university. ACADEMICIA: An International Multidisciplinary Research Journal. https://saarj.com. ISSN: 2249-7137 Vol. 10, Issue 8, August 2020.R. 562-567. Impact Factor: SJIF $2020=7.13$

12. Atoeva M.F. Pedagogical Tests As An Element Of Types of Pedagogical Technologies. The American Journal of Applied Sciences, 2 (09), (TAJAS) SJIF-5.276 DOI-10.37547 / tajas Volume 2 Issue 9, 19.09.2020. ISSN 2689-09. 92 The USA Journals, USA www.usajournalshub.com/index.php/tajas 164-169. Imp.5.2.

13. Atoeva M.F. The problems of preparing students for the use of school physical experiment in the context of specialized education at secondary schools. European Journal of Research and Reflection in Educational Sciences Vol. 8 No. 9, 2020 ISSN 2056-5852. R.164-167.

14. Saidov S.O., Fayzieva Kh. A., Yuldosheva N. B., Atoeva M.F. The Elements Of 
Organization Of The Educational Process On The Basis of New Pedagogical Technologies. The American Journal of Applied Sciences, 2 (09), (TAJAS) SJIF-5.276 DOl-10.37547 / tajas Volume 2 Issue 9, 19.09.2020. ISSN 2689-09.92. The USA Journals, USA www.usajournal shub.com/index.php/ta jas 164-169. Imp.5.2.

15. Atoeva M.F. Frequency of teaching physics. Post-graduate student and applicant. Moscow, 2010. -№6. - S. 41-43.

16. S.K. Kaxhorov, Atoeva M.F. Frequency as a pedagogical regularity of teaching physics. Pedagogical sciences. -Moscow, 2010. -№ 6. - P. 56-59.

17. M.F. Atoyeva. Interdisciplinary relations in physics course at specialized secondary education. The Way of Science. Volgograd, 2016. - No. 9 (31). - P. 22-24.

18. M.F. Atoyeva. The significance of periodicity at teaching physics. The Way of Science. - Volgograd, 2016. -№ 10 (32). P.62-64.

19. Atoeva M.F. The effectiveness of teaching electrodynamics based on the technology of periodicity. The Way of Science. Volgograd, 2016. -№ 10 (32). - P.65-66.

20. M.F. Atoyeva. Use of Periodicity in Teaching Physics. Eastern European Scientific Journal. -Düsseldorf-Germany, 2017. No. 4. -P. 35-39. 